\title{
An Architectural History of the Canterbury Hebrew Congregation
}

\section{Gay Sweely}

During the 1960s and 70s, many important structures in Christchurch were unsympathetically demolished due to the lack of heritage laws and the introduction of new construction codes for withstanding seismic activity. Noted historian John Wilson recorded some of these buildings in Lost Christchurch (1984). Four years later, the heritage-protected synagogue of the Canterbury Hebrew Congregation in Gloucester Street met the same demise. In the middle of that year, the site contained only rubble from a building that had been loved and admired by many: Jews, local residents and visitors alike. Today, few people walking in Gloucester Street would realize that a once-stately polychrome building proudly occupied what is now a vacuum of asphalt paving.

This paper outlines the design, construction and ultimate loss of T. S. Lambert's Christchurch synagogue. To contextualize the building's design and construction, the paper also considers earlier synagogues in Australia and other New Zealand cities. The final section discusses the loss of the Gloucester Street building and the re-use of various elements from it in the replacement, Durham Street synagogue, which continues to serve the Canterbury Hebrew Congregation's present-day needs.

\section{T. S. Lambert's Synagogue}

In the early 1860s, gold was discovered on the West Coast near Hokitika, and a small group of Jewish miners and merchants established a congregation on the goldfields. When the gold deposits subsequently dwindled, the Jews of Hokitika and South Westland settled in the Canterbury area. The Torah from the Hokitika congregation was sent and proudly displayed in Christchurch (CHC, 1963b: 11). This combined congregation offered lectures, meetings and social functions during the late 1860s, as recorded in various articles, advertisements and notices in the local newspaper, the Press.

In 1870, the Rev. Isaac Zachariah arrived in Christchurch from the West Coast and, until 1905, provided substantial leadership, hitherto offered only by lay members. During the 1870s, New Zealand Anglo-Jewish Associations and the Jewish Philanthropic Society were formed, as well as a Hebrew school (though informal until 1890) for the study of Judaic literature in the Canterbury Hebrew Congregation. ${ }^{1}$

Although the Canterbury Hebrew Congregation was steadily growing, Jewish immigration to New Zealand had historically been low. In the 1870s and 80s, Jews immigrating to New Zealand and Australia were no longer only from Great Britain. The majority of the new immigrants were eastern-European Jews escaping waves of pogroms and massive episodes of oppression. The Hebrew congregation in Canterbury had expanded so much by 1875 that a meeting was held

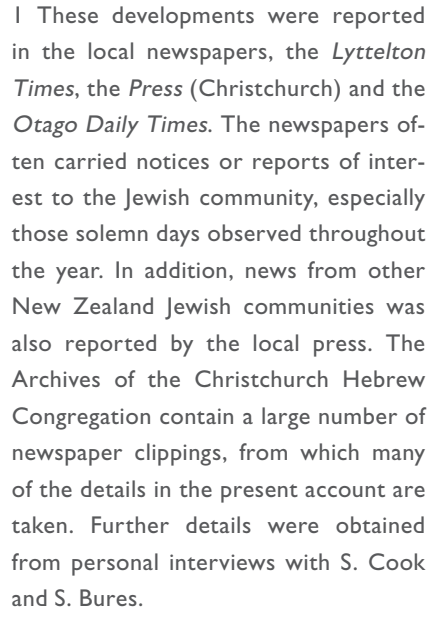

I These developments were reported in the local newspapers, the Lyttelton Times, the Press (Christchurch) and the Otago Daily Times. The newspapers often carried notices or reports of interest to the Jewish community, especially those solemn days observed throughout the year. In addition, news from other New Zealand Jewish communities was also reported by the local press. The Archives of the Christchurch Hebrew Congregation contain a large number of newspaper clippings, from which many of the details in the present account are taken. Further details were obtained from personal interviews with S. Cook and S. Bures. 
Fig. 1: The circular Star of David
stained-glass window in Lambert's

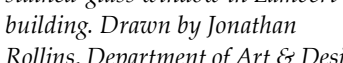
Rollins, Department of Art \& D D Fig. 2: The Arr. Drawn by
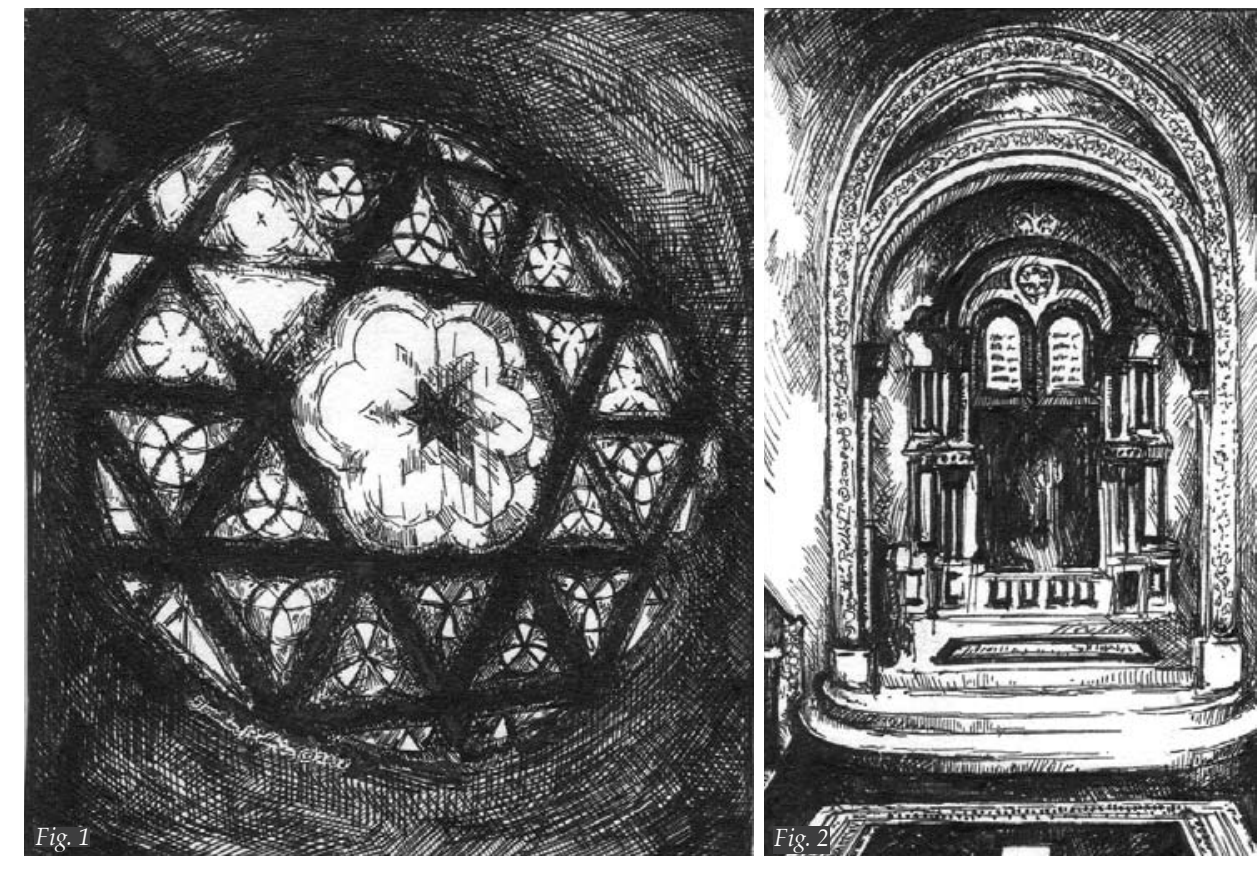

to discuss more suitable accommodation. A building committee was selected to decide on congregational requirements, available funding and an appropriate architect The Canterbury-area Jewish community banded together and raised in a very short time, $f 4,000$ - quite a feat for such a small congregation. The promi-

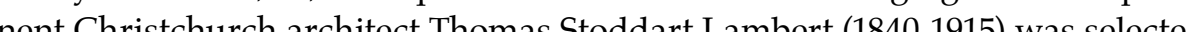

Lambert's designs in Canterbury prior to 1880 had included churches, residences, schools, commercial buildings and rural hotels. The Jewish community would have been aware of many of these stuctures, but they were probably more aware of his commercia B. Simpson, as Marks was a member of the Canterbury Hebrew Congregatio (CHC, 1963c: 11). Born in Selkirk, Scotland, Lambert served his articles there before extensive travel and a brief residence in London. He arrived in New Zealan in early 1866, working on various structures north of the Wellington Province. In 1874, he moved to Wellington but was not optimistic about building prospects there and thus moved to Christchurch, where he entered the office of Frederick Strouts, who in 1871 had been one of four founding members of the Canterbury Association of Architects (Stacpoole, 1976: 163). Under Strouts' supervision, Lambert "personally surveyed the entire city of Christchurch" (Cyclopedia, 1903: 581). In 1877, Lambert formed his own architectural firm. He was most likely selected for the new synagogu contracts [were] finished without extras, and their total cost [was] usually somewhat under
his written estimate previously given" (Cyclopedia, 1903: 581).

A successful local Christchurch contractor, W. Prudhoe, was selected for the synagogue construction. Prudhoe had served as contractor for architect Samuel Farr, known for the Christchurch Mechanics Institute, and had completed several Government contracts (Akaroa Civic Trust, n.d.). An 1880 newspaper article reported that the new synagogue design was unique and that its façade design would be clad in blue, white and yellow stone, with exterior walls of brick. As the account notes, the new synagogue was completed in November 1880:

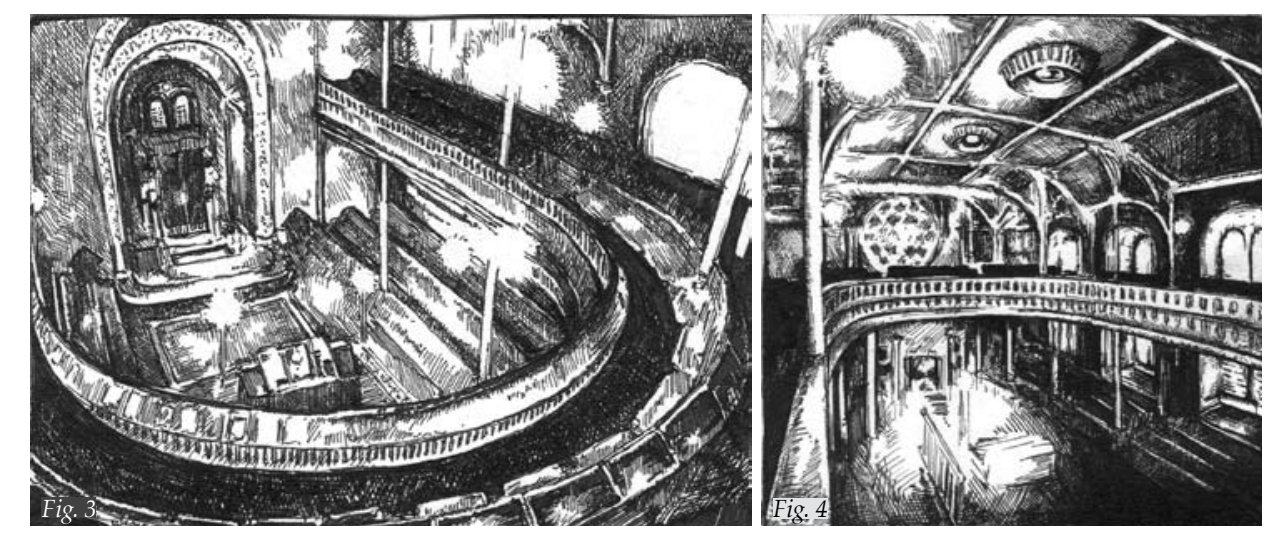

The exterior fronting Gloucester Street East has an elevation of much originality, the chief feature in it being a large circular window, the tracery of which takes the form of the double triangle (Fig 1) On either side are smaller windows harmonising with the fir a pair of handson through a vestibule, paved with marble in a lozenge pattern.... Two doors hung so as to open in either direction, lead to the main building. Here, the most striking feature is the decorations at the South end of the building. This is where the Ark is situated (Fig. 2). The Ark itself is a large receptacle, lined with red velvet and enclosed with two massively carved sliding doors. In front of these hangs a white silk veil... The gallery is supported by iron fluted pillars, having capitals ornamented with lilies and pomegranates (Figs. 3 and 4).... The lighting by day is provided by four double windows on each side, filled with cathedral glass, and outlined by glass of more brilliant colours, the same colours being introduced into the large North window. (New Synagogue, 1880: 2)

The Christchurch synagogue was an eclectic mixture of architectural styles. Lambert designed in the classical style, as well as the Venetian Gothic and Gothic styles. ${ }^{2}$ It was a basilica-like structure: the white vertical rusticated bands could easily be massive columns or pilasters. A classical pediment appeared at the apex, but Gothic window hoods broke up the classical approach.

Lambert's use of rustication and constructional polychromy placed the synagogue comfortably within the Canterbury architectural aesthetics of the time. Lambert effectively married clasical, Gothic and Scottish elements into a very distinctive South Ihand design. The small Canterbury congregation seeming was pleased with b was pleased with both the interior design, which was reminiscent of British synagogues, and the ornamental exterior. "It had taken more than a year in building and all the records show that it was considered by all present to be a very handsome building and worthy of the Jewish citizens of Christchurch at that time" (CHC, 1963c: 14).

\section{Early Synagogues in New Zealand}

The mid-nineteenth-century English Jews who settled in New Zealand would have been familiar with many synagogues around Great Britain, and perhaps in Continental Europe and Australia. On the continent, architects of synagogues built during this period were experimenting with various styles, such as Roman-
Fig. 3: The lower level. Drawn by
Ionathan Rollins. Fig. 4: The interior, showing the ceiling,
gallery and circular window. Draun by golatery and circul
Jonathins

"'The great majority of the new larger
Cmmercial buildings of the 1870 s and 1880 s, and beyond .... were talianate, a cyle common in other New Zealand cittes... [and] many of the city's imposing bert" (Wilson et al., 2008: 81). 
esque, Byzantine, classical, Moorish and German Gothic. However, this eclecticism in design did not surface in the architecture of English Jewry (for example Hambro and Bevis Marks in London), for reasons of discretion and financial constraints. The Gothic Revival style of the Church of England was held in anathema by Jews for its Christian connotations.

Jewish settlers remaining in Australia after the gold rush of 1851 moved to urban areas, founded minyans (ten Jewish males, the number required by Judaic law to hold a worship service), and built synagogues. The first colonial synagogues were temporary wooden, box-like structures. As their communities expanded and became more established, permanent synagogues were planned, designed and erected. The Great Synagogue at Sydney, facing Hyde Park, was built in 1878. The interior is characterized by its "semi-centrally planned seating arrangement" and gallery (Crighton, 1985: 153; also see Summerson, 1963: 338). Designed by Thomas Rowe, it is a magnificent building mixing the Byzantine style with Gothic characteristics. The twin towers on the façade are of Pyrmont sandstone, choricter style. The spacious interior (a) panelled and groned ceiling. The stained-glass windows and fine light pendants render the interior jewel-like.

A minyan was achieved in Auckland in the 1840s, and these Jewish males held services in a warehouse loft in Shortland Street, owned by David Nathan until $1847^{3}$ "The number of male worshipers was very few, as at this time there were only thirty-three Jews altogether in Auckland - men, women and children" (Balkind, 1928: 23). From 1847 until 1858, a separate room in the warehouse served as the worship area for the small congregation. Sometime in 1858, the Aucklan congregation leased a one-storey wooden building under construction, in Emily Place at the top of Shortland Street. Since the building was only one storey, the women had to be seated behind the men, instead of in galleries, as is the Jewish custom (Rivkin, 1971: 339-40; Hachlili, 1998: 24, 84).

The small Jewish congregation in Wellington preceded the formation of any congregation in the South Island. A minyan was established during the 1840s, and this congregation held temporary services in the residence of the congregation's President for Shabbat (Sabbath) worship. ${ }^{5}$ This synagogue served the Wellington community well until growing numbers in the late 1860 s dictated that larger premises were needed.

The first Jewish settlements in the South Island were at Nelson and Timaru. The congregations of Dunedin and Canterbury were organized later, most likely due to the fact that these were Christian church-related, planned settlements. Similar to the other Jewish settlements in the collon, Dunt pynagogue was a wooden structure on lease-hold land in George Street that was purchased repaired and altered in the late 1850s (Balkind, 1928: 10). The 43-male congre gation adhered to the English Jewish rituals and placed themselves under the jurisdiction of Dr N. M. Adler, the Chief Rabbi in London, with services conducted by lay members and readers.

The Dunedin Jewish congregation definitely viewed themselves as fortunate. Not only did they possess a magnificent Pentateuch (the scroll of the Mosaic Law essential to every synagogue) and a baldachin (a canopy for special ceremonies, such as weddings), they also were granted a separate cemetery by the Otag
Provincial Council. By the early 1860s, the Dunedin congregation was outgrowing its wooden synagogue and had to consider building a larger structure on a "more suitable and central site" (Balkind, 1928: 12). Thus, in early 1863, the congregation advertised for a permanent minister and began to discuss the feasibility of a new synagogue in a different location.

In 1863, William Henry Clayton (1823-77) was awarded the tender for the new Dunedin synagogue. When Clayton became a partner of William Mason, he brought with him this commission for the synagogue. Clayton, who is best known for his wooden Government Buildings in Wellington (1876), Governmen House in Wellington (1868-71), and the Christchurch Government Buildings in Cathedral Square (1875-77), had only recently arrived in Dunedin from Tasmania. He was appointed Colonial Architect in 1869 (Crighton, 1985: vi).

The Dunedin synagogue, the southern-most synagogue in the world (Judd, n.d.), was designed in a c The symmetrical design has a vertical, uplifting emphasis created by tapering columns. ${ }^{6}$ The Corinthian columns correspond aesthetically with the Hebrew inscription on the frieze. Other than the inscription and the Magen David (a sixpointed star) in the centre of the pediment, the only other Jewish emblem on the façade was a menorah (a candelabrum for Jewish services) above the apex of the perim whe "wh few religi. sical style also conveyed a desirable sense of antiquity (Gunman, 1981: 103-21).

\section{The Canterbury Hebrew Congregation}

By 1860, small Jewish congregations had been established in the major cities of the North and South Islands, with the exception of Christchurch. The Jews had not sailed to New Zealand as members of any organized group, but it can be ssumed that they were seeking a land where they could freely practise their faith and safely raise their families. Early New Zealand Jewish-immigrant Louis Edward Nathan was most likely in search of a nascent mercantile area and a new life in Canterbury: a predominantly High Church Anglican colony. Nathan, later elected as the first president of the Canterbury Hebrew Congregation, was one of the first Jews in Canterbury (CHC, 1963a: 13; Clements, n.d.). ${ }^{7}$ The first record of the presence of a Jewish community on the Canterbury Plain was printed in a newspaper "call for subscriptions" to aid former Moroccan Jews. ${ }^{8}$ Nathan returned to England (perhaps for supplies or his family) and arrived back in Canterbury by 1864 (CHC, 1963b: 1). Prior to that time, there is no record of any recognized structure or site of Jewish worship in the Canterbury region. In January 1864, a congregation was established, and Nathan elected to the chair.

The group met regularly in Nathan's home in St. Asaph Street, officiated by Mark Marks (CHC, 1963c: 11). To build the first Canterbury synagogue, $£ 300$ was subscripted immediately, and a request for government assistance discussed. Sulces and many conmer mo che also held the same month. In June, tenders for the design were called for in the local newspaper.
6 The style of the Dunedin synagogue Jong the lines of More Park, Hertfordphe espectally the central pedmented 7 Nathan served as president of the anterbury Hebrew Congregation from The Jewish Central Commitros in Ltetton (Call for Subscriptions, 1860: 5). 


\section{Fig. 5: The exterior of fhe new Durham
Street synagogue. Photograph by Street synagogo
Gay Sweely.}

9 It may be assumed that Mountfort the architect of the early shul, was sim. ply too busy to design the replacement continuing his building programme St. John the Baptist (1859-82) for the Rev. Beniminin Woolley Dudley, was also supervising construction of the Christchurch Cathe 1964; see also Sweely, 1988: 6-23).

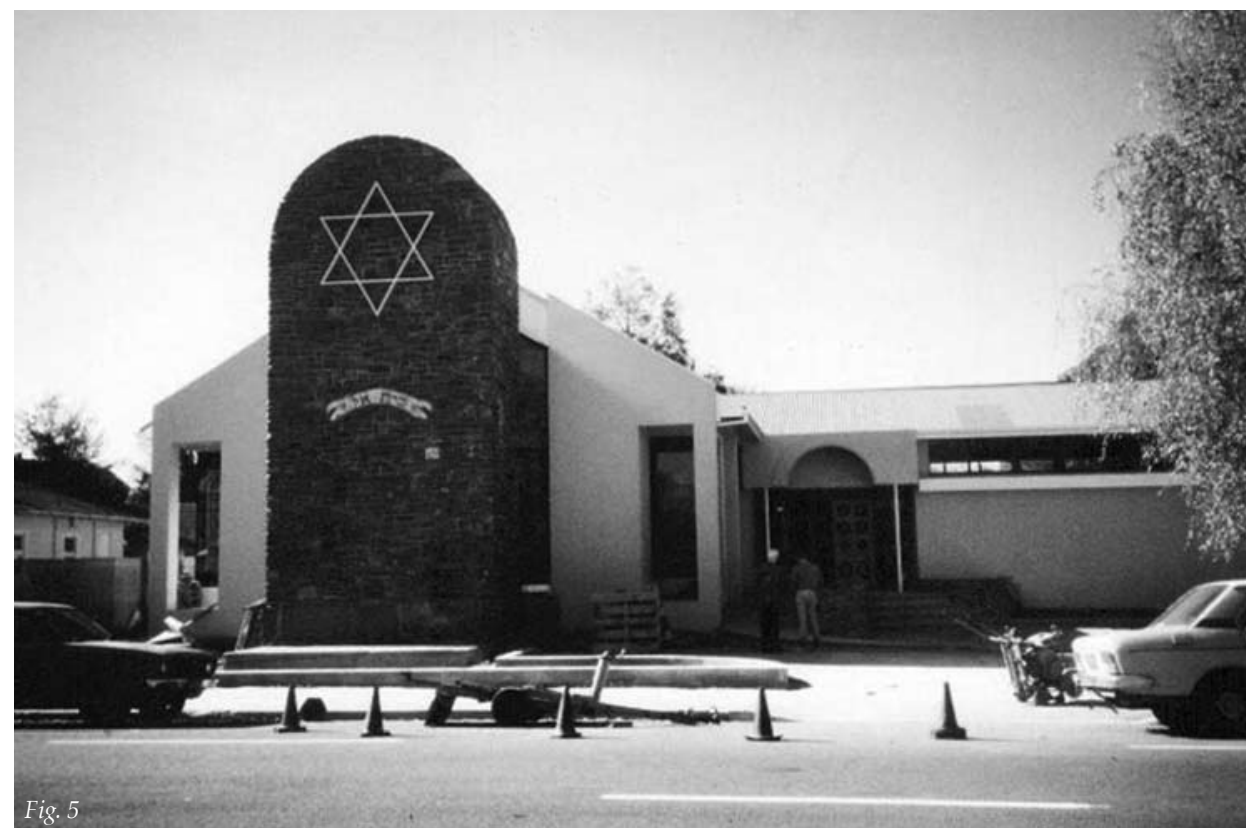

The first building planned for the Jewish community in the Canterbury region was a small wooden shul (in Yiddish, a house of worship). It was decided that Divine Services would be held in this structure until a proper synagogue could be financed, but the completion of this modest building was a testament to a group of people who had survived displacement and relocation (CHC, 1963b: 11). Unfortunately, nothing, at present, is known of the form or appearance of this structure. Primarily intended to serve as a building for Hebrew instruction the function almost dictates a modest design - most likely resembling a small wooden-gabled school of the era.

The architect for the 1864 shul was Benjamin Woolfield Mountfort (1825-98), who was, like Lambert, a member of the Canterbury Association of Architects (Stacpoole, 1976: 163). At the time Mountfort submitted his design proposal for the Canterbury shul, he was also overseeing work on the new Canterbury Provincial Council Buildings (1858-65). The site for the shul was on inner-city Gloucester Street, only a short distance from the Provincial Council Buildings. By 1865, the ture and items for its services from Europe and Palestine.

In the latter 1860s and early 1870s, as outlined at the beginning of this paper . (1879-80. proper synagogue, leading to the realization of Before construction could start, Mountfort's old shul building was removed to an adjoining, recently acquired, property, to be used for the congregation's educational and social activities (Lochhead, 1999: 318). The site vacated by the shul wa then prepared for the new synagogue (CHC, 1963b: 1). M. Harris, congregation president, performed the ceremonial laying of the foundation stone, and a sealed jar was placed inside the foundation stone to commemorate the event. ${ }^{9}$

Lambert's synagogue admirably served the Canterbury Hebrew Congregation for over 100 years. It was the site of a plethora of lectures, bazaars, fund-raising ventures for aid to Jews around the world, and solemn events, such as the observance of Queen Victoria's passing, as well as its significance in the region as

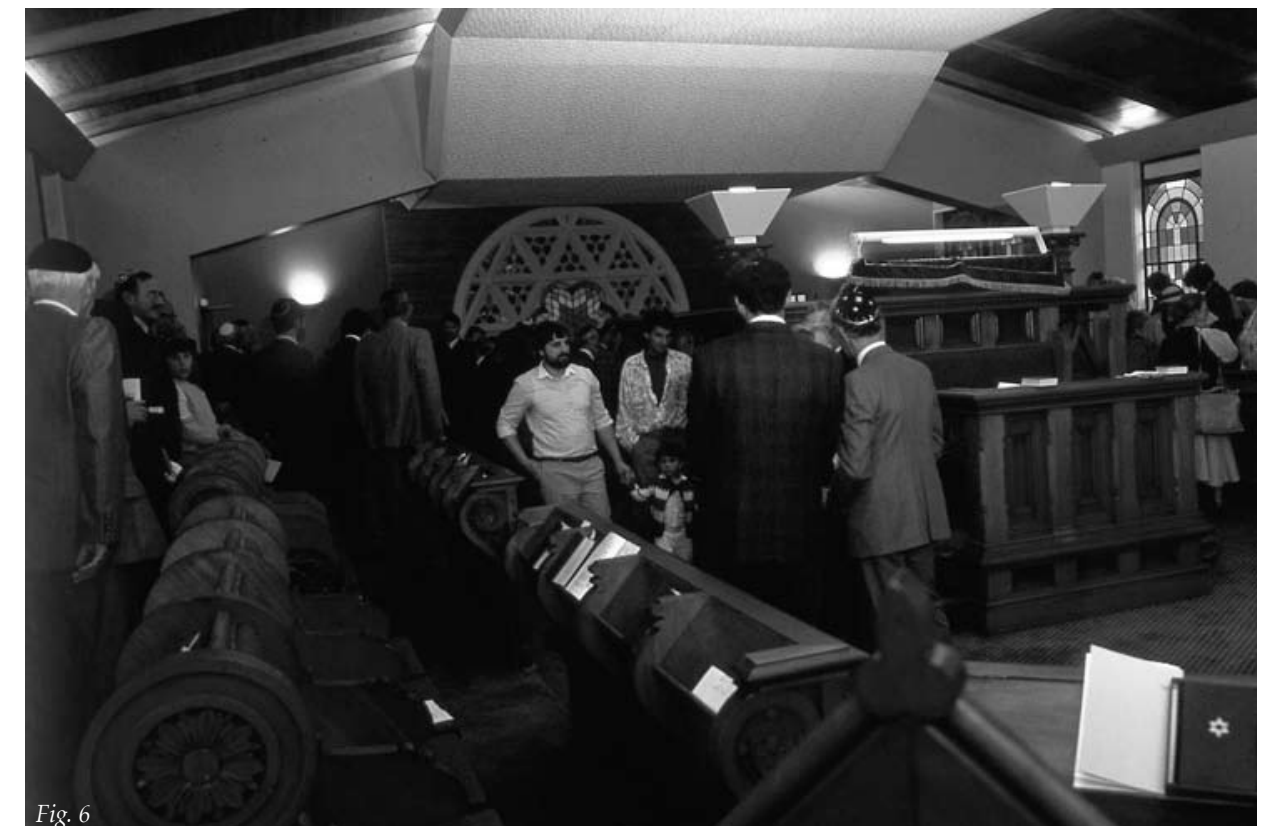

a Class C heritage building of the New Zealand Historic Places Trust (Cattrell, 1985: 62). Renovations were completed in 1963, prior to the observance of the centennial of the Canterbury Hebrew Congregation in Christchurch (CHC, 1963c 40). Lambert's synagogue was a survivor, by the mid-1980s nestled between lowrise mixed-use buildings, including a Masonic Lodge, an art gallery and, a little to the west, Christchurch Girls' High School.

\section{Another New Synagogue for Christchurch}

In 1987, serious cracks in the foundations of Lambert's building were of great concern to the congregation. While the architect's design was a monument to the community and the synagogue had served its purpose and the community most admirably, time had inevitably taken its toll. The only solution was to meet elsewhere. The congregation purchased a former Brethren Assembly Hall in Durham Street, to be redesigned to include a social hall, offices, kitchen and a worship area. This task was given to the Christchurch firm of Skews, Hay and Archer. A new synagogue on Durham Street was also commissioned.

In order to retain some of the beautiful decorations from Lambert's building - and a fragment of Jewish history in Canterbury - Samuel Cook, a prominent Christchurch contractor and synagogue member, was directed to salvage important portions of the old synagogue for re-use in the new building. In early 1988, the old façade was scaffolded to remove the Star of David circular window, entrance doors and stained-glass windows. Stone from the Gloucester Street front and Durham Street side was carefully removed and incorporated into the new façade and walls. Lastly, Cook's crew painstakingly removed the inner doors, bim $h$, seats and desks, the upper portion of the Ark with the Decalogue (the Ten Commandments), and the Ark sliding doors. All of the wooden items had been constructed from native kauri and were remarkably well preserved. By 6 May 1988, one lone section of rubble was all that remained on the site of Lambert's historic synagogue. 
The Canterbury Hebrew Congregation's new synagogue was consecrated on 14 May 1988, with about 120 people attending the service, led by the Rev. Jeffrey Leverton. The exterior included the nineteenth-century stonework preserved and used in new ways - in paths, border walls and the frontal piece, which resembles a stone tablet (Fig. 5) - while behind those officiating at the service were the redesigned stained-glass windows from Lambert's synagogue, enshrined by a kauri feature wall and now at eye level (Fig. 6).

\section{Reflections}

Expatriate Jews, part of a never-ending worldwide diaspora of expatriates, sought final refuge in the South Island of New Zealand in the latter portion of the nineteenth century. In addition to unconventional meeting places, the Canterbury Hebrew Congregation built three houses of religious worship in the region. Lambert's synagogue (1880-1988) should be remembered in the architectural history of the Jews of New Zealand as a jewel built for a small group of expatriate settlers on the Canterbury Plain, seeking to find their way in a time of upheaval, displacement and relocation. These expatriates, like so many before them, were seeking a way to express their religious views in art and architecture in a new land. During the centenary celebrations of 11 August 1963, a special prayer was presented by the clergy officiating in honour of the Canterbury Hebrew Congregation that built "such a beautiful Synagogue ... a source of great pride and inspiration to all of us who are the inhagogn of those wout Jew pride and (CHC, 1963 to all . The who are the inhertors of those worthy Jewish Pide agogue was a major heritage loss for Christchurch and the Jewish community of New Zealand. Its replacement with a utilitarian carpark continues to rankle with historians, although more generally, the memory of Lambert's synagogue has started to fade and it is hoped that this research will help to keep it alive.

\section{References}

Akaroa Civic Trust (n.d.). Walk Akaroa. Retrieved 15 August, 2007, from http://www. historicakaroa.co.nz/buildingdetail

Balkind, V. F. (1928). A Contribution to the History of Jews in New Zealand. Unpublished Masters Thesis, University of New Zealand, Canterbury.

Call for Subscriptions (1860, April 18). Lyttelton Times, p. 5

Canterbury Hebrew Congregation [CHC]. (1963a). Canterbury Hebrew Congregation History. Archives of the Canterbury Hebrew Congregation, Christchurch.

Canterbury Hebrew Congregation [CHC]. (1963b). Centennial Address. Archives of the Canterbury Hebrew Congregation, Christchurch.

Canterbury Hebrew Congregation [CHC]. (1963c). The First One-hundred Years of the Canterbury Hebrew Congregation. Christchurch: The President and Board of Management of the Canterbury Hebrew Congregation.

Cattrell, J. (Ed.) (1985). Historic Buildings of Canterbury and South Canterbury: A Register of Cltif

Clements, M. (2008). Pers. comm. to the author (29 June).

Clements, M. (n.d.). Notes on Jewish Participation in New Zealand History. Retrieved 2 July, 2007, from http://www.nzjewisharchives.org/history.htm

Crighton, S. A. (1985). William Henry Clayton: Colonial Architect. Unpublished Masters Thesis, University of Canterbury, Christchurch.
The Cyclopedia of New Zealand (1903). Canterbury ed. vol. 3. Christchurch: Horace J. Weeks. De Breffny, B. (1978). The Synagogue, London: Macmillan.

Goldman, L. M. (1958). History of the Jews in New Zealand, Wellington: A. H. \& A. W. Reed. Gunman, J. (Ed.) (1981). Ancient Synagogues: The State of Research. Chico, California:

Hachlili, R. (1998). Ancient Jewish Art and Archaeology in the Diaspora. Leiden, Netherlands: Brill. udd, S. (n.d.). Jews in New Zealand. Retrieved 10 July, 2008, from http://vital.org.nz/ nzjews.html

Kadish, S. (2006). Jewish Heritage in England: An Architectural Guide. Swindon, England: English Heritage

Krinsky, C. H. (1996). Synagogues of Europe: Architecture, History, Meaning. New York: Courier Dover Publications.

ochhead, I. (1999). A Dream of Spires: Benjamin Mountfort and the Gothic Revival. Christchurch: Cante A Dry University Press.

Macdonald, G. R. (1964). The Macdonald Dictionary of Biography. Christchurch: Canterbury Museum.

New Synagogue (1880, December 16). Press, p. 2.

Rivkin, E. (1971). The Shaping of Jewish History: A Radical Interpretation. New York: Charles Scribner's Sons.

Stacpoole, J. (1976). Colonial Architecture in New Zealand. Wellington: A. H. \& A. W. Reed. Summerson, J. (1963). Architecture in Britain: 1530-1830. 2nd ed. Baltimore: Penguin Books.

Sweely, G. C. (1988). The Anglican Church of St. John the Baptist, Rangiora, 1860-1988 Unpublished manuscript held in Christchurch Library Archives, Christchurch.

Wilson, J. (1984). Lost Christchurch. Auckland: Lansdowne Press.

Wilson, J. et al. (2008). Contextual Historical Overview for Christchurch City: Fina Draft Report for Comment. Christchurch City Council, Christchurch. Retrieved 2 July 2008, from http://www.ccc.govt.nz/Christchurch/Heritage/Publications/Christchurch City ContextualHistoryOverview/ChristchurchCityContextualHistoryOverview 